\title{
STATES WITHOUT CITIES: DEMOGRAPHIC TRENDS IN EARLY JAVA
}

\author{
Jan Wisseman Christie
}

\section{Introduction}

Java's place in the demographic literature is an interesting one. If one accepts the census figures produced at Raffles' behest, then it appears that the population of the island in 1815 stood at approximately 4.5 million. In 1900 it was close to 30 million. This apparent explosion in population, in the absence of any substantial net immigration, has been the focus of a good deal of comment for decades, drawing attention from other, potentially more significant, aspects of Java's demographic history. Now that recent studies have begun to cast doubt upon the accuracy of the early nineteenth century population estimates, suggesting that the population of rural areas was, for a number of reasons, grossly under-reported, it appears that Java's population growth may not have been quite as astonishing as it once seemed. Such studies do, however, highlight an important aspect of the past distribution of the population on the island, particularly in the Javanese-speaking areas of central and east Java: despite its heavy population, Java has not until recently been significantly urbanized. The 1815 figures indicate that at that time there were only five towns on the island with more than 20,000 inhabitants; at the end of the nineteenth century, towns of that size or larger still contained less than 3 percent of the population, and 90 percent of the population lived in communities of fewer than 5,000 inhabitants, ${ }^{1}$ despite the administrative and eco-

I wish to thank the British Academy for providing the funds that supported part of the research discussed below. I would also like to express my gratitude to the members of the Pusat Penelitian Arkeologi Nasional for the aid and facilities provided. My sincere gratitude goes to Drs. Boechari for sharing with me some of the epigraphic research in which he is currently engaged, and to Drs. Mundarjito for discussing with me some of the survey material which he is currently assembling.

${ }^{1}$ Peter Boomgaard, Children of the Colonial State: Population Control and Economic Development in Java, $1795-1880$ (Amsterdam: Free University Press, 1989), p. 111; discussion of the early nineteenth-century figures can be found on p. 166. Some of the recent debates are summarized in G. J. Hugo, T. H. Hull, V. J. Hull, and G. W. Jones, The Demographic Dimension in Indonesian Development (Singapore: Oxford University Press, 1987). 
nomic restructuring and rapid growth of rail links brought about by the Dutch colonial government.

This dispersal of population, particularly in central and east Java, did draw the attention of colonial commentators, who tended to explain the demographic situation by reference to the structure of the Javanese colonial economy, which acted as a feeder of unprocessed and semi-processed agricultural produce to European industries and markets. Most assumed that the colonial economy damped the native tendency towards urban growth. Anthony Reid has taken this argument a step further by suggesting that European interference in Southeast Asia actually reversed trends towards urbanization, and that in the sixteenth and seventeenth centuries Southeast Asia had been one of the most urbanized areas of the globe. ${ }^{2}$

Although Reid's suggestion may be a valid one in the case of coastal trading states whose port cities suffered under colonial rule, there is no evidence that Java was significantly urbanized before the arrival of the Dutch. The port towns of the north coast of Java described by Tomé Pires early in the sixteenth century, based upon actual observation rather than hearsay, were surprisingly small, most having fewer than 2,000 inhabitants. ${ }^{3}$ The situation seems not to have changed significantly before the middle of the eighteenth century, the size of towns fluctuating wildly over periods of months or years depending upon the fortunes of war and the movements of rural populations, ${ }^{4}$ but showing no overall tendency towards long-term growth. In the period of peace following the signing of the treaty of Giyanti in 1755, the rise in population in rural districts far out-stripped that of the towns. ${ }^{5}$ Dutch colonial policies of the following century, far from impeding urban growth, seem actually to have encouraged it.

The underlying pattern of growth of population in central and east Java seems to have been, during the pre-colonial perod, that of short-term fluctuation in very mobile urban populations balanced against long-term (though not necessarily steady) growth in density of rural population in core regions of states. Not only did villages apparently grow at the expense of larger enclaves, but the data suggest that as villages grew they tended frequently to break down into two or more nucleated hamlets rather than acquire the characteristics of

2 A.J.S. Reid, "The Structure of Cities in Southeast Asia, Fifteenth to Seventeenth Centuries," Jourmal of Southeast Asian Studies, 11, 2 (1980): 235-50.

3 A. Cortesão (ed. and trans.), The Suma Oriental of Tomé Pires and the Book of Francisco Rodrigues (London: The Hakluyt Society, 1944), vol. 1, pp. 175-200. Figures for the population of settlements presented by Tomé Pires fall into two classes: those based upon hearsay (for Děmak and the state in the interior) and those based upon direct Portuguese observation (most of the Pasisir states). The figures based upon hearsay tend to be large. According to the head of Tuban, the lord of the interior state had some 200,000 fighting men at his disposal, and the state was "thickly populated, with many cities, and very large ones"; Pires, however, felt that this was clearly an exaggeration (pp. 175-76). Děmak, "according to what they say," was reported to be a town of some 8,000 to 10,000 dwellings and its lord had some 30,000 fighting men at his disposal from the country as a whole (p. 185); yet direct observation appears to have indicated a lower population for the town (p. 186). The figures based upon direct observation reveal that the ports of the other Pasisir states of the time were quite small. Tuban, for instance, had only some 1,000 inhabitants within its walls (p. 190), yet its lord could apparently raise 6,000 to 7,000 fighting men from the town and its limited hinterland (p. 192). The port of Gresik, "the great trading port, the best in all Java," which had a seasonally large foreign and archipelago trading population, appears to have had relatively few permanent residents. The population of the smaller states resided mainly in villages which were themselves apparently rather small.

${ }^{4}$ M. C. Ricklefs, "Some Statistical Evidence on Javanese Social, Economic and Demographic History in the Later Seventeenth and Eighteenth Centuries," Modern Asian Studies 20, 1 (1986): 1-32.

${ }^{5}$ Peter Carey, "Waiting for the 'Just King': The Agrarian World of South-Central Java from Giyanti (1755) to the Java War (1825-30)," Modern Asian Studies 20, 1 (1986): 59-137. 
small towns. ${ }^{6}$ Most of the towns and cities of modern Java owe their size, and many their very existence, to Dutch intervention. It will be argued below that this underlying pattern of relatively small-scale residential clustering within a densely populated rural landscape is a very old one, and that the economic and administrative structures of early Javanese states were not only adapted to this settlement pattern, but may in fact have helped to perpetuate it.

\section{Background and Sources}

The very limited archaeological data available at present suggest that rudimentary states of some sort may have begun to appear on the north coast of Java as early as the last three centuries B.C.E. The initial stages of political development seem to have occurred, at least in part, in response to an intensification of regional trade. This trade brought tin, copper, and iron into metal-poor Java; it also brought valuables in the form of large bronze drums from northern Vietnam. The distribution of these drums along the coasts of the Java and Banda Seas suggests that the Javanese may have dominated the spice trade of the eastern islands as early as the second or third century B.C.E., which may in turn explain the unusually large concentration of these drums in Java itself. With the connection of this regional trade network into the Old World trade system in the first century C.E., Javanese states were exposed to ideas from the Indian subcontinent, and the long process of "indianization," a phenomenon related to the growth of these states, had begun. Thus, by the time that legal documents were first recorded on permanent materials on the island, early in the ninth century, Javanese states could draw upon perhaps a millennium of accumulated political tradition and economic development.

Despite a century of archaeological investigation on the island, these legal documents, preserved on copper plate or on stone, remain the best source of data relating to demographic and economic development in the heartlands of central and east Java. Most of the recovered structural remains, which are largely religious and frequently monumental, are located in the two regions known to have formed the foci of the major states of pre-colonial Java: the uplands skirting Mount Merapi and the Perahu chain in central Java, and the Brantas river valley and adjacent Malang uplands of east Java. Unfortunately, dense modern settlement and heavy dependence upon wet-rice farming, along with certain geological factors, 7 have made the location of non-religious sites nearly impossible. Only the politically marginal region of Rembang, Pati, and Blora, near the north coast, has provided any useful data on early settlement patterns. ${ }^{8}$

Written sources do to some extent compensate for the gaps in the archaeological record. The most important records in this respect are the indigenous inscriptions in Old Javanese

\footnotetext{
${ }^{6}$ Boomgaard, Children, p. 115.

${ }^{7}$ In the immediate environs of the central Javanese temple of Borobudur, to the south of Magelang, some 207 sites of the eighth to early tenth centuries have been found to date, including the remains of 43 temples and small shrines: Sub-Konsorsium Sastra dan Filsafat, Laporan Kerja Lapangan, Borobudur (Jakarta: Departemen Pendidikan dan Kebudayaan, 1976). However, further to the east, in the region between Yogyakarta and Solo, sites of the late first millennium C.E. have been buried under layers of lahar ranging in depth from two to seven meters in some areas, and almost no surface finds of material from the period are found in this area. Similar problems are caused in the east Javanese heartland by volcanic activity in the Malang uplands and adjacent areas, and by flood-borne alluvium in the Brantas delta.

${ }^{8}$ E. W. van Orsoy de Flines, "Onderzoek naar en van keramische scherven in de bodem in Noordelijk MiddenJava, 1940-42," Oudheidkundig Verslag (1941-47), Bijlage A; Jan Wisseman, "Archaeological Research in Rembang District, north central Java, 1975," Indonesia Circle (1977): 8-14.
} 
language. The surviving corpus includes over 300 sima (tax transfer) documents and a much smaller number of jayapattra (lawcourt decision) records, most of which deal with financial matters. The majority of these documents were issued between the beginning of the ninth century and the end of the fourteenth, the largest number of original charters being issued late in the ninth century, early in the tenth, and again during the first half of the eleventh century. The early decades of the fourteenth century saw a spate of reissues of earlier charters, many of which were updated in response to changing circumstances. From the middle of the fourteenth century a major literary work, the Nagarakrtagama, has survived which contains passages describing the landscape and settlements of the time in east Java. Added to these sources are the small collection of descriptions of Java recorded by a series of foreign observers, geographers, and trade officials over this period of several centuries. These last are far from reliable and can thus be used only when their contents appear to confirm information available from local sources.

\section{Early Settlement Patterns and Demographic Trends}

The impression one receives from Javanese written sources of the ninth to fourteenth centuries is that the vast bulk of the population lived in rural settlements of varying size, complexity, and antiquity, but all of which were primarily farming communities. These settlements were distributed somewhat unevenly across a landscape dominated by a series of volcanoes, many of which were at least partially active, and by two major and numerous minor river systems. Before 929 C.E. the dominant state on the island clung to the skirts of the volcanoes of central Java; after that date the center moved east to the Brantas river delta and the adjacent Malang uplands of east Java. This move appears to have occurred in response to at least two pressures: the long-term positive pull of the Brantas delta region and its trading opportunities during a period when Java was probably gaining trade at the expense of its more economically volatile rival Srivijaya9; and the short-term, catastrophic effects of volcanic activity in central Java during the later ninth and early tenth centuries. ${ }^{10}$

\footnotetext{
${ }^{9}$ Jan Wisseman Christie, "Patterns of Trade in Western Indonesia: Ninth through Thirteenth Centuries A.D." (University of London: PhD thesis, 1982), vol. 1, pp. 30-33.

${ }^{10}$ See the following: R. W. van Bemmelen, "The Influence of Geographical Events on Human History. (An example from Central Java)," Verhandelingen van het Koninklijk Nederlandsch Geologisch-Mijnbouwkundig Genootschap, geologische serie 16, (1956), pp. 19-36; H. Th. Verstappen, "Geomorphological Observations on Indonesian Volcanoes," in Drie Geografische Studies over Java (Leiden: Brill, 1963), pp. 237-51; M. Boechari, "Some Considerations on the Problem of the Shift of Mataram's Centre of Government from Central to East Java in the 10th Century," in Early South East Asia, ed., R. B. Smith and W. Watson (London: Oxford University Press, 1979), pp. 473-92. It appears, from more recent observations, that the layer of lahar which swamped the temple of Sambisari, near Yogyakarta, to a depth of seven meters, was not the result of one overwhelming flood of volcanic mud and sand, but probably of at least five separate episodes of deposition during a relatively brief period. There is no evidence at present that the surface of any of the major layers weathered sufficiently for vegetation to gain any widespread foothold before the next layer was deposited. The volcanic activity which produced this outflow of lahar may have built up over some decades. Deposits of volcanic sand relating to this period of volcanic activitiy are shallower to the west, in the region of Borobudur, but those at the site of Borobudur itself indicate that the settlement suffered a series of minor volcanic episodes before it was abandoned to the meter of sand dumped on it. Occupation of the site just below the monument appears to have begun late in the eighth century. At least two, and possibly three, narrow bands of sand interrupt the occupation layer accumulated before the early tenth century, indicating that there was a series of minor eruptions towards the end of the period of occupation. As in the seventeenth century, these may have been accompanied by a series of earth tremors. In the seventeenth century the tremors and eruptions caused widespread alarm and fostered the belief that the ancestors and spirits were unhappy with the incumbent political order. A parallel period of political instability occurred between 884 and 898 C.E., when, according to the recently discovered Wanua Tengah charter of 908 C.E., two rulers were driven out of the palace within a year of taking the throne, a third "fled the palace" after eight years in power, and a fourth survived only four years on the throne. Political instability during that four-
} 
Since no inscription dating to the period after 928 C.E. has been found in central Java, it is assumed that a large proportion of the population followed the political center east to the Brantas delta. As, however, there is some evidence for continuity of place names in central Java between the ninth and later centuries, it seems likely that central Java was never actually depopulated, although it certainly became a political backwater.

After 929 C.E. the political center remained for some centuries in east Java, although during the later eleventh century the east Javanese state appears to have split into two smaller states, one on the coast and one in the interior, centered at Kadiri on the upper Brantas. These states were reunited once more in the early thirteenth century. The unified east Javanese state reached its peak in the fourteenth century, at which point it appears to have exercized some degree of power over much of the island of Java, as well as those of Madura and Bali, and to have included within a wider sphere of political clients many of the coastal states of eastern Indonesia, Borneo, and the Malacca Straits. By the fifteenth century, however, this state began to disintegrate, as a number of port enclaves along the north coast of Java began to pull away, financed by a major trade boom in the region, to form the Pasisir trading states. Shortly after 1500 C.E. the interior state was overrun from the north.

Against this background of shifting political fortunes, certain demographic trends appear to have been cumulative and largely unidirectional, reflecting several underlying developments: growth in population, growth in wealth both from agriculture and trade, and administrative attempts to cope-with varying degrees of success-with these long-term trends.

Several factors, including location of political centers and trade routes, as well as distribution of soil types, available surface water, and the steepness of incline, influenced the size and location of settlements. Judging from the distribution of sima charters and the number and size of settlements mentioned in them, it appears that settlement in central Java, during the ninth and early tenth centuries, formed a series of enclaves in the more fertile upland regions of Kedu, Magelang, Wonosobo, and the area to the north and east of Yogyakarta. Archaeological data seem to indicate that most villages were located along the banks of rivers draining the Merapi and Perahu massifs, between 100 and 400 meters above sea level. ${ }^{11}$ This, at least, is where almost all monumental remains and inscriptions have been found, along with the large number of scattered yoni and lingga stones which may indicate the location of early village shrines. ${ }^{12}$ While pollen samples from the site of Borobudur, south of Magelang, indicate that by the time of the construction of the monument late in the eighth century the site was located in a large tract of agricultural land and palm groves, ${ }^{13}$ the inscriptions indicate that most villages had direct access to forest resources.

Although this general pattern of uneven, perhaps even discontinuous, distribution of population within states was maintained over a number of centuries, certain important differences between patterns in the core regions of central and east Java were apparent by the

teen-year period may well have been fed by natural disaster. The Wanua Tengah charter has been transliterated by Drs. M. Boechari, but has yet to be published.

11 Mundarjito, personal communication.

12 Jan W. Christie, "Raja and Rama: the Classical State in Early Java," in Centers, Symbols and Hierarchies: Essays on the Classical States of Southeast Asia, ed., L. Gesick (New Haven: Yale University Southeast Asia Studies Monograph 26, 1983), p. 16.

13 J. Nossin and C. Voute, "Notes on the Geomorphology of the Borobudur Plain (Central Java, Indonesia) in an Archaeological and Historical Context." Paper delivered at the Symposium on Remote Sensing for Resources Development and Environmental Management, Enschede, The Netherlands, 1986. Proceedings, p. 858. 
tenth century and tended to become more marked over time. The center of the independent state which existed in east Java during the eighth and early ninth centuries appears, like that of its sister polity in central Java, to have been located on the upland skirts of active volcanoes, in this case the Malang valley. After this state was annexed by that of central Java, later in the ninth century, population appears to have begun to build up in and around the Brantas delta in the lowlands. Following the shift in political center to the east, the rate of population growth in the delta region appears to have accelerated considerably, and the distribution of monumental and epigraphic remains indicates that location of settlement from this period onwards was as much influenced by a network of roads and overland tracks as by the drainage system. The description, published in about 916 C.E. by the Arab writer Abu Zaid, of what can only have been the Brantas region of east Java, ${ }^{14}$ provides a vivid, if perhaps somewhat exaggerated image of what the region's settlement looked like:

The authority of the Maharaja [of Zabag] is exercized over these various islands and the island in which he resides is extremely fertile, and patches of settlement succeed each other without interruption. A very trustworthy man affirms that when the cocks crow at daybreak, as in our country, they call out to each other throughout the whole extent of a hundred parasangs [@500 kilometers] or more, showing the uninterrupted and regular succession of villages. In effect, there are no uninhabited places in this country and no ruins. He who comes into the country when he is on a journey, if he is mounted he may go wherever he pleases; if he is tired or if his mount has difficulty in carrying on, then he may stop wherever he wishes.

By the early eleventh century the landscape in the delta region was already a crowded one. The settlements of Cane, Patakan, and Baru, lying just to the south of Surabaya, ${ }^{15}$ each

14 G. R. Tibbetts, A Study of the Arabic Texts containing Material on South-East Asia (Leiden: Brill, 1979), p. 33. Tibbetts is inclined to believe that the term Zabaj was originally applied by the Arab writers to the island of Java, and that it only later became confused with references to Srivijaya, during a period when there was little direct Arab contact with the region and changes were occurring in the regional balance of economic power. The fact that successive authors plundered earlier manuscripts for information led to a great deal of confusion. At the time that Abu Zaid wrote, however, there seems to be no doubt that Zabaj was Java (p. 100-16). Chinese records and inscriptions from mainland Southeast Asia, as well as archaeological data, tend to support the impression that from the late eighth to the early or mid tenth century, Java was the most important trading power in the maritime region of Southeast Asia (Christie, "Patterns," pp. 30-33ff.).

15 The charters are: Cane (1021 C.E.), Patakan (eleventh century), and Baru (1030 C.E.). Sources for the charters referred to in this article are as follows: In J.L.A. Brandes, Oud-Javaansche Oorkonden, ed., N.J. Krom (The Hague: Bataviaasch Genootschap, 1913): Baru (1030 C.E.) Ix, Cane (1021 C.E.) lviii, Hantang (1135 C.E.) lxviii, Jaring (1181 C.E.) lxxi, Kamalagyan (1037 C.E.) lxi (and also in Christie, "Patterns," vol. 2, pp. 492-503), Kambang Putih (eleventh century) cxviii (and also in Christie, "Patterns," vol. 2, pp. 528-29), Kemulan (1194 C.E.) lxxiii, Padlegan (1117 C.E.) lxvii, Panumbangan (1120 C.E.) lxix, Patakan (eleventh century) lix, Pěrtapan (1198 C.E.) lxxv, Petungamba (1269 C.E.) lxxx, Sangguran (928 C.E.) xxxi, Tuhañaru and Kusambyan (1323 C.E.) lxxxiii. In A.B. Cohen Stuart, Kawi Oorkonden in Facsimilie met Inleiding en Transscriptie (Leiden: Brill, 1875): Lintakan (919 C.E.) i, Waharu (931 C.E.) vii. In Th. G. Th. Pigeaud, Java in the 14th Century, 4 vols. (The Hague: Nijhoff, 1960-63): Ferry Charter (1358 C.E.) vol. 3, pp. 156-62. In H.B. Sarkar, Corpus of the Inscriptions of Java (Calcutta: Firma K.L. Mukhopadhyay, 1971-72): Mantyasih (907 C.E.) lxx. In W.F. Stutterheim, "Transscriptie van een Defecte Oorkonde op Bronzen Platen uit het Malangsche," Oudheidkundig Verslag (1928), pp. 105-8: Manañjung (eleventh century) and also in Christie, "Patterns," pp. 504-12. In W. F. Stutterheim, "Oorkonde van Balitung uit 905 A.D. (Randoesari I)," Inscripties van Nederlandsche-Indie 1 (1940): 3-28: Randusari 1 (905 C.E.). In F.H. van Naerssen, Oudjavaansche Oorkonden in Duitsche en Deensche Verzamelingen (Leiden: University of Leiden Proefschrift, 1941): Watukura (ninth century) viii, ix, x, and also in Christie, "Patterns," p. 527. Wanua Tengah (908 C.E.) has been transcribed by Drs. M. Boechari, who has also transcribed and translated the charter of Garamān (1053 C.E.); both of these have yet to be published. The charter of Dhimanāśsama (eleventh century) has plates scattered through three collections: plates 8,9, and 10 appear in Brandes, Oudjavaansche as charter number cxii; plates 1(?), 7 , and 10 appear in P.V.van Stein Callenfels, "Stukken betrekking hebbend op oud-Javaansche opschriften in de 
appear to have supported populations exceeding a thousand persons, belonging to over three hundred households; their markets were large and frequented by foreign traders. The charter of Kamalagyan (1037 C.E.) lists seven settlements lying along the twenty-five kilometer stretch of river between Kamalagyan and the port of Hujung Galuh on the coast, along with an unspecified number of holy places of nine different classes. ${ }^{16}$ This rise in density of population continued up the length of the Brantas, particularly around Kadiri and the area to the east of Blitar, where overland routes between the mountains descended to the river, ${ }^{17}$ and along the overland routes themselves. ${ }^{18}$ In the middle of the fourteenth century the Brantas and Solo rivers were crossed by a network of roads served by a lengthy list of villages with official ferry charters. The incomplete set of copper plates of the Ferry Charter (1358 C.E.) lists thirty-four such ferry-operating villages in the lower Brantas region alone and over twenty on the lower stretch of the Solo, downstream from Bojonegoro. Since an entire plate bearing the beginning of the list is missing, the total number of ferry settlements along the two rivers may have exceeded 150.19

MacDonald's guess ${ }^{20}$ that the population of Java could have reached five million by the fourteenth century may not be wildly inaccurate. Yet from none of the sources, either historical or archaeological, does there emerge a single clear description of a settlement which can confidently be called a city. In fact, despite the greater tendency of settlement in east Java's lowlands to conform to a man-made pattern of distribution, and despite the clear increase in both the size of the population and the number of settlements in the broad lowland plains area, there appears to have been no pressure for a classic central place hierarchy of economic centers to evolve. The only concentrated accumulations of population to appear before the fourteenth century seem to have developed around one or two ports, and even these concentrations seem to have fallen short of the size and stability that characterize true urban centers. The capital of Majapahit itself seems to have been little more than a series of large royal and elite compounds with attached religious monuments, surrounded by a cluster of large villages.

The continuing diffuseness of settlement was probably, in fact, due partly to the nature of the political centers in Javanese states, and to the considerations that governed their locations and their movements. Literary sources suggest that the residence of the ruler (kadatwan in Old Javanese, kraton in Modern Javanese) was, by the eleventh century at least, broadly similar in function, structure, and residential population to the kratons of the Later Mataram

Bibliotheque Nationale te Paris," Oudheidkundig Verslag (1924), pp. 23-27; and half of plate 12 was transcribed by F.H. van Naerssen, "Inscripties van het Rijksmuseum voor Volkenkunde te Leiden," Bijdragen 97 (1937): 507-8. See also Christie, "Patterns," pp. 513-21.

16 The holy places mentioned included sima, kalang, kalagyan, thäni jumput, wihara, sala, kamulan, parhyangan, and parapatapan. Of this list, the first four were, in fact, special-status communities with religious connections of some sort in this context. The wihara was a monastery, sala a type of temple, kamulan apparently an ancestor shrine, parhyangan a place associated with the spirits, and parapatapan meant "the several hermitages of ascetics."

17 See the charters of Padlegan (1117 C.E.), Hantang (1135 C.E.), Panumbangan (1120 C.E.), Jaring (1181 C.E.), Pertapan (1198 C.E.), Kemulan (1194 C.E.), Petung-amba (1269 C.E.), Tuhañaru and Kusambyan (1323 C.E.), and others from the upper Brantas region.

18 See especially Kemulan (1194 C.E.), Panumbangan (1120 C.E.), and Petung-amba (1269 C.E.), as well as Hantang (1135 C.E.).

${ }^{19}$ See Pigeaud, Java, vol. 3, pp. 156-62, and commentary, as well as J. Noorduyn, "Further Topographical Notes on the Ferry Charter of 1358," Bijdragen 124, 4 (1968): 460-81, for a summary of other discussions of the topographic information in the charter.

${ }^{20} \mathrm{P}$. MacDonald, "An Historical Perspective to Population Growth in Indonesia," in Indonesia: Dualism, Growth and Poverty, ed., R. G. Garnaut and P. McCawley (Canberra: Australian National University Press, 1980). 
period. While there are indications in the legal literature of a growing social and ceremonial distance between the ruler and the populace after the tenth century, as numbers of officials multiplied and the chain of intermediaries between royal patron and village client lengthened and each official enlarged his own retinue of clients, there is no real evidence that palace settlements became truly urban either in size or in function.

In fact, one characteristic shared by states both in central and east Java was the relative mobility of the political center. The royal center appears to have moved at least twice in the eighth and ninth centuries in central Java, each time shifting further to the south and east and apparently locating itself in a region already heavily populated. One of the moves probably carried it at least sixty kilometers. Then in 929 C.E. the kadatwan was shifted some six hundred kilometers to the east. Although this was the most striking of the moves of the palace, it was far from the last. The royal center moved between the Malang uplands and the Brantas valley a number of times over the centuries before coming to rest at Trawulan in the Brantas delta during the late thirteenth or fourteenth century. The period between the mid tenth and early thirteenth centuries appears to have been marked by at least three civil wars, each necessitating at least one move of the political center. This degree of mobility of the royal settlement appears to reflect a relatively low level of investment in the physical premises and the surrounding physical infrastructure. The fact that abandoned royal centers appear to have left little but rural villages in their wake, as in the case of that mentioned in the thirteenth century Sumanasantaka, ${ }^{21}$ seems to indicate that whatever population build-up occurred outside the palace gates was not translated into formal or enduring urban structures. Nor were royal centers apparently located in settlements which already had major economic functions. Rulers in both central and east Java avoided, for strategic or symbolic reasons, placing their palaces in port enclaves before the fifteenth century, and the heads of the various watek tax groupings appear to have maintained their own residences away from the palace settlement; consequently, administration, patronage, and trade wealth did not converge on the same settlement, as was the case in the contemporary states of the Malacca Straits. Nor did they apparently remain attached to fixed settlements for any great length of time.

The patterns of distribution of settlement and the direction of the flows of wealth and power across the Javanese landscape appear to have been for centuries in a constant, if not always rapid, state of flux. Until the fifteenth century, when the three centuries of disintegration and warfare began on the island, these fluctuations occurred against the background of, and perhaps partly in response to, a substantial rise in population and a marked proliferation and growth of rural settlements. Two clear trends emerge from the archaeological and epigraphic records. The first, which is most clearly attested to archaeologically, is of the expansion of states through pioneering in peripheral areas. The sudden growth of population and proliferation of settlements in the marginal Rembang-Pati-Blora region after the turn of the millennium appears to have occurred as a result of this process. ${ }^{22}$ The sima charters of certain strategic peripheral areas indicate that rulers actively promoted this pioneering through the granting of tax concessions. Grants stipulating that swidden land or forest be converted to sawah (irrigated rice land) in order to settle and stabilize territory bordering major road and river connections with the coast were made both in central and east Java. In central Java between 872 and 882 C.E. a series of at least ten sima grants was made to several temples in the mountains to the north of Magelang, along the route to the north coast. In many cases these grants involved tgal (dry field, swidden land) or sukat (brush

21 154.7: see P. J. Zoetmulder, Old Javanese-English Dictionary (The Hague: Hijhoff, 1982), p. 1932.

22 Wisseman, "Archaeological Research," p. 13. 
land, fallowed swidden), which was to be converted to sawah..$^{23} \mathrm{~A}$ few years later similar grants were made in east Java along the route between the Malang uplands and the coast, the stated reason being the danger presented to travelers by the tgal fields along the road. ${ }^{24}$ At the beginning of the tenth century, during a period of expansion and consolidation in central Java, another grant was made in connection with forest and sawah land on the slopes of mounts Sumbing and Sundoro to the north of Magelang for the stated purposes of protecting the high road. ${ }^{25}$ At the same time in east Java a grant was made concerning forest to be cleared for sawah because the forest was said to present a danger to traders and people traveling to the coast. ${ }^{26}$

The second trend, most apparent at the level of the village community, was the coupling of growth with fission.

\section{Settlement and Community}

The diffuseness and mobility of political and economic foci within early Javanese states was echoed at the village level. Unlike ancient villages on the mainland of Southeast Asia, which often remained in one place long enough to build up substantial mounds reflecting centuries or even millennia of occupation, Javanese villages seem not to have occupied the same precise location for more than a few generations. This does not, however, mean that there was no long-term continuity in villages or that the communities broke up and reformed in other places. Villages remained fixed within a defined region and they had boundaries that apparently remained stable over a period of centuries. Village names appearing in charters of the tenth century can still frequently be found on maps of the twentieth century, particularly in the Brantas valley. In some cases the boundaries of old sima territories can still be traced on modern maps. Land, once cleared, bunded, and irrigated for rice cultivation, was not abandoned casually, even if a proportion of the population moved or died during periods of warfare. However, within the fixed village territorial borders, the community's population appears to have shifted the location of their dwellings frequently enough to prevent the build-up of any tell-tale mounds.

The relative impermanence of dwelling units was apparently one of the factors underlying what was perhaps the most interesting development in the Javanese interior before the fifteenth century. This process, which might be termed the "disintegration" of the village, seems to have been provoked by population growth. It appears to have contributed, in turn, to certain administrative changes. This process of the restructuring of the rural communities and their relations to the court is reflected in the changing terminology applied in the legal literature to these settlements. Between the early-ninth century and the mid-fourteenth century several clear shifts occurred in the terms by which communities were defined for administrative purposes. The terms are, in order of appearance, wanua, thāni/karaman, duwan/duhan $i$ dalem thäni, paraduwan/paraduhan, and desa or dapur.$^{27}$

23 See M. Boechari, Prasasti Koleksi Museum Nasional I (Jakarta: Museum Nasional, 1986), inscriptions E5, E6, E7, E9, E10, E15, and E18; in Machi Suhadi and M.M. Sukarto, Laporan Penelitian Epigrafi Jawa Tengah (Berita Penelitian Arkeologi 37, Jakarta: Departemen Pendidikan dan Kebudayaan, 1986), inscriptions 2.7.1, 2.7.3, 2.7.4, and 2.7.6.

${ }^{24}$ Sarkar, Corpus, lvi and lvii.

${ }^{25}$ Ibid., lxx.

${ }^{26}$ A. M. Barrett Jones, Early Tenth Century Java from the Inscriptions (Dordrecht: Foris Publications, 1984), p. 181.

27 J. Wisseman Christie, "Wanua, thāni, paraduwan: The 'Disintegrating' Villages of Early Java?" in Texts: Oral and Written Traditions, ed. W. Marshall (Bern: University of Bern, 1991). 
The oldest term to be applied to Javanese settlements in the legal literature is wanua. It appears in the earliest surviving sima document, dated 804 C.E., and with a single known exception was the only term used in charters until 991 C.E.. The term is a very old one. Given the wide distribution of the word and its variants in maritime Southeast Asia, the Pacific, and Madagascar, it was certainly present in the basic proto-Austronesian vocabulary by the time the Austronesians moved south through the Philippines, about five thousand years ago, with a meaning that must have been something like "settled territory" or "dwelling place." In the Old Javanese legal literature the term had several related meanings. It meant both "group" and "settled territory." The "group" was in all cases human and the word appears to carry overtones of internal structure or stratification. The closest English language equivalent is "community." When the term was placed in the landscape, it referred to settled land belonging to a structured community whose rights derived from deified ancestors rather than from the state. The wanua in this sense was acknowledged by the court to have had clearly identified boundaries and to have included all of the land within those borders, cultivated or not. This territory appears to have been large, based perhaps upon the territorial requirements of mixed agricultural systems including swidden. The formulas in the charters relating to wanua land include such phrases as, "the forests, swidden fields, and rivers, in the valleys and on the hills," "their valleys and mountains ... their sawah and orchards," "their sawah, dry rice fields, marshes and orchards," and others in the same vein. The wanua was administered by a council of heads of land-owning householdsthe karaman-a number of whom held named community offices. However, no single figure can be identified as headman in the legal literature before the fourteenth century, and it is doubtful that such a figure appeared uniformly until much later, when state authorities (frequently Dutch) imposed headmen on villages for administrative convenience. ${ }^{28}$

The legal charters of the ninth and tenth centuries refer to only three classes of settlement: the wanua, the religious community (kahyangan), and the palace enclave (kadatwan), as in the Mantyasih charter of 907 C.E.:

"O ye Holy Spirits of past [kings], who once were lords of the wanua, masters of the kahyangan, builders of kadatwan. ..."29

All communities subject to sima grants before 991 C.E. were called wanua, and so were the surrounding communities who sent witnesses to the ceremonies and all of the communities from which the middle and lower-ranking state officials were drawn. The use of this single term in these charters did not reflect poverty of vocabulary. Judging from the Indian literary works available by that time in Old Javanese-notably the Ramayana, and the Adiparwa and other parts of the Mahabharata-the full range of Sanskrit terms for settlement and city was available to the court clerks who inscribed the charters. There appears to have been very little resistance at the time to borrowing Sanskrit terminology where it proved to be useful, and a wide range of legal, political, and administrative terms were already part of the working vocabulary of courtier and villager alike. The more obvious Sanskrit terms which could be used to describe a city-pura and nagara-didn't filter into the Javanese vocabulary until the thirteenth century, and even then, in Javanese legal contexts (rather than "Indian" literary contexts) the terms appear to have referred only to the palace enclave and its dependent settlement complex, replacing and amplifying the older term kadatwan. Use of the terms in the thirteenth and fourteenth centuries does not appear to reflect the addition of

28 J.C. Breman, "The Village on Java and the Early-colonial State," Journal of Peasant Studies 9, 4 (1982): 189-240.

${ }^{29}$ Sarkar, Corpus, $1 \mathrm{xx}$. 
a new category of settlement to those recognized, although it may indicate some growth in the size of the population living just outside the palace walls.

The names of over four hundred wanua appear in the surviving records from central Java, most of which date to the brief period between 850 and 928 C.E. It remains unclear what proportion of the total number of settlements belonging to the central Javanese state and located in that region this represents. The fact that few overlaps occur from one charter to the next in the names of wanua from which witnesses to the various sima ceremonies were invited (in nearly a hundred charters) probably means that those listed represent less than half of the total extant in the regions where grants were made. Since both religious foundations and sima territories that supported them formed a series of clusters, rather than being uniformly distributed across the settled landscape, there must have been a substantial number of areas whose wanua were not mentioned at all in the sima charters.

Most wanua subject to tax transfers appear to have had a number of close neighbors. Some of these wanua tpi siring ("adjacent bordering settlements") who sent witnesses to sima ceremonies clearly shared boundaries with the sima villages. Since, however, the number of wanua tpi siring mentioned in any one charter ranged from one or two to over sixty, as in the case of Randusari I, issued in 905 C.E., the term appears to have been applied somewhat loosely to villages within a recognized catchment region that cross-cut the 120 or so watek tax-groupings (the precursors to later appanage holdings) mentioned in texts of this short period.

The ninth- and tenth-century wanua were by no means uniform blocks of population. They varied considerably in size, in wealth, and possibly in internal structure and economics. These differences seem to have become more marked over time. By the end of the ninth century the sima charters mention large and small (magöng, madmit) wanua, whose representatives were ranked accordingly in the ceremonial gift lists. Lists of heads of households in ninth-century settlements affected by sima transactions range in length from a handful to nearly a hundred, and these households appear to have represented only one class in the community hierarchy, so it is conceivable that some settlements could have harbored close to a thousand individuals. In the large wanuas of the ninth and tenth centuries, two, three, or even four or more individuals shared the same community office. By the early tenth century, sub-communities within the wanua were often distinguished. These appear to have comprised groups of residents whose primary occupation was not farming, as in the case of the merchant group (kabanyagan) of Galuh, mentioned in the Lintakan charter of 919 C.E. At the same time there appear to have been named territorial subunits of at least some wanuas.

It may have been in response to this growth in diversity of rural communities that, late in the tenth century, the ancient term wanua was replaced in the legal literature by the terms thani and karaman, the word karaman referring to the body of heads of household who formed the community council, and the word thani, which referred to the place itself, emphasizing its rural character. This new terminology proved less enduring than the older word. By the middle of the eleventh century the word thani was beginning to give way to the term duwan (later also duhan), meaning "hamlet," found in the phrase duwan $i$ dalem thani ("hamlet inside the thani"). One thani could consist of several duwan, as in the case of Baru (Baru, 1030 C.E.), whose four duwan, named Punasa (? "purified"), Gunung ("mountain"), Dèpur ("cluster"), and Pkan ("marketplace"), comprising about 100, 40, 70, and 90 households respectively, provide some indication of the manner in which the community was distributed. At much the same time the term babad ("forest clearing, pioneer settlement") begins to make a regular appearance as a description of a settlement sub-unit belonging to 
the community, and from the way in which it is mentioned it appears that the babad settlement may in many cases have lain outside of the old community boundaries. If so, then at least some of the pioneering settlement in east Java appears to have been carried out under the auspices and administration of existing communities, through the creation of daughter settlements and the annexation of territory. By the beginning of the twelfth century, the term thani appears to have been largely replaced by the word paraduwan ("the several duwans") or phrases indicating the number of duwan. Most communities whose duwan were enumerated at this time comprised about four or five hamlets, but others incorporated up to a dozen, particularly in the upper Brantas valley where there appears to have been more room for territorial expansion. In these large, sprawling settlements the old term wanua occasionally appeared in the phrase wanua tengah ("core/original settlement"), but not in its old general usage. Late in the twelfth century a new term, desa, borrowed from the Sanskrit, began slowly to replace other terms for the community as a whole, while in the fourteenth century, the term dapur ("cluster") appears to have taken over some of the meanings of duwan. Usage appears to have remained in flux until the Dutch standardized the use of the word desa five centuries later.

This rapid series of shifts in terminology, after what may have been several thousand years of use of the term wanua, could reflect changes in administrative relations between court and populace, or changes in the demographic structure of Javanese states. In fact, it probably reflects both. Only two of the terms-desa and possibly thani-were borrowed from Sanskrit. The word desa meant "area, region" in Sanskrit, and it was originally used in Old Javanese with that meaning, only very gradually taking over the meaning of settlement territory. The term thani probably derives from the Sanskrit term sthanin ("abiding, permanent") or sthaniya ("large village, town"). The original Sanskrit term never appears in the legal literature in connection with settlements, and the Javanized version, thani, is so stable in orthography both in the charters and in metric literature that it seems likely that the term had been thoroughly adapted to the local context, acquiring a new set of indigenous meanings, well before it began to replace the term wanua. Both of the borrowed terms have one common feature, however, which may have influenced their adoption: they both implied relative largeness in scale. The replacement of wanua by thani may reflect a perceived growth in the average size of communities, although the constant coupling of the term with that of karaman, distinguishing the place from its population may also indicate some adjustment in administrative relations between state and village, foreshadowing the growth in direct patron-client links between official and individual household, bypassing the village. This shift may also represent an attempt on the part of the tax-collecting authorities to redefine the status of communities by abandoning a term that carried too many overtones of political autonomy.

Subsequent changes, which followed one another in such rapid succession from the eleventh century onwards that they overlapped even in the same charters, tell us a good deal about the changing demographic structure at the village level and administrative attempts to deal with them. The population of east Javanese states appears to have risen fairly consistently from the early tenth century through the fourteenth, despite at least three periods of internal strife: during the second two decades of the eleventh century, and again in the second half of that century, followed by another, possibly briefer struggle early in the thirteenth century. Not all of the excess population was syphoned off into pioneering communities on the states' peripheries. Established communities grew, but instead of forming ever larger clusters of dwellings and taking on the characteristics of small towns, they apparently began to break up into smaller residential units. This process was almost cer- 
tainly under way as early as the ninth century, in central Java, where larger communities developed multiple sets of officials, probably representing different hamlets within the communities' territories. Named subunits of wanuas appear in sima charters by the early tenth century, not all of them located within the boundaries of the original wanua territory. This trend may reflect a growing confidence in the state's power to maintain order, as well, perhaps, as a beating back of the surrounding forest and its dangers, since convenience and pressures to reduce social tensions appear to have over-ridden considerations of defense in the location of housing. It is at about this time that domestic architecture in Java appears to have begun to change, bringing houses, once set high on pilings, much closer to the ground. This in turn allowed for the expansion of roofed domestic space, but characteristically, the process of enlargement appears to have led to the development of clusters of small structures rather than to an expansion of space under one roof, judging from the structures illustrated in temple reliefs. The processes of growth and sub-division appear to have been linked at every level in Javanese society.

After the move of the main political center to east Java, this trend towards the subdivision of larger communities accelerated. By the early eleventh century many of these communities were expanding into the remaining forest areas and claiming as part of their establishment newly-cleared land apparently beyond the borders of the communities' territories. The daughter communities set up in these forest clearings remained attached to the original community - a fact that may explain some later law suits between communities over conflicting administrative rights. ${ }^{30}$ That the communities continued to exercise rights over clearly bounded territories at this time is indicated by the boundary pillars mentioned in descriptions of the borders of tax-transferred territories, and the assumption made by all charters that these borders would never be breached. It appears that communities could expand, but were not expected to shrink. Expansion, however, brought the subdivisions of the community more and more into the fore in legal documents. Hamlets within the village were listed as a matter of course by the mid-eleventh century, although the community continued to be recognized as a unit with administrative rights. The hamlets do, however, appear to have developed stable identities under the umbrella of the larger community. For instance, the edict of Panumbangan (1120 C.E.) refers to a community at a crossroads to the east of Blitar as lima duwan i panumbangan $i$ dalem thani ("the five hamlets of Panumbangan inside the thani"), listing the five hamlets as Palampitan ("rattan-mat place"), Kamburan (?), Padagangan ("trading place"), Byetan (?), and Kidul-ning-Pasar ("south of the covered market"). A century and a half later, the charter of Petung-amba (1269 C.E.), referring to the same community as the paraduhan panumbangan ("the several hamlets of Panumbangan") lists at least three of the original hamlets: Kamburan, Padagangan, and Kidul-ing-Pasar, as well, possibly, as two new units: Banak ("goose") and (?) Tiwir. The inscription is too fragmentary for it to be clear whether the other two original hamlets survived intact, disappeared entirely, or developed new identities, but three of the hamlets clearly retained enough of their identity to keep the same names, and probably roughly the same locations, even if some degree of shift and expansion had occurred. ${ }^{31}$

\footnotetext{
${ }^{30}$ One such dispute is recorded in the Majapahit period Walandit inscription from the Malang uplands, where the dispute hinged upon the claims of autonomy by Walandit and the counter claims of authority by Himad; while these were both holy places, the dispute appears to have concerned financial dispositions and Himad's claim that Walandit was a daughter community of some sort. See J. G. de Casparis, "Oorkonde uit het Singosarische (Midden 14e Eeuw A.D.)," Inscripties van Nederlandsch-Indie i (1940), pp. 50-60.

31 Brandes, Oud-Javaansche, lxix and lxxx.
} 
The increase in prominence of hamlets within a village in tax transfer charters occurred as state authorities began to shift their tax concessions, in at least some cases, away from entire-and by then often large-community corporations, to the smaller subunits under community control. This shift in focus of tax-gathering interests was consolidated in the twelfth century, when the term paraduwan or paraduhan ("the several hamlets") replaced older terms for the community as a whole. The term thani, like the word wanua, was relegated to use in a few limited contexts, as it lost its former range of meanings. The community had become a sum of its parts, many of which were more or less self-contained farming communities. Other sub-communities, of a non-farming nature, emerged as regular features of these expanded settlement complexes: the incorporated groups of artisans (kalang), small religious establishments (kalagyan), and merchant enclaves (kabanyagan) were the three classes of non-farming community most frequently mentioned.

Late in the twelfth century, this expansion of the community and the rural sprawl it created resulted in the adoption of yet another term for community: the word desa, and in the following century the term dapur, which seems to refer to a cluster of housing, joined the word duwan/duhan in references to the smallish residential subunits of the community. During a period when old charters were being reissued and updated, in the fourteenth century, several terms occasionally appeared in the same inscription, apparently in an attempt to avoid some of the confusion that the accumulated changes in legal terminology must have created.

What seems clear from this record of administrative attempts to accommodate changes in the demographic structure of increasingly populous states is that the changes to which the authorities were reacting were not those leading to increased concentration of population, but rather to the proliferation of smallish residential clusters within an increasingly hierarchical administrative structure. The hierarchy was expanding at the bottom as well as at the top, and it was not a hierarchy that depended upon size of coresidential population. The only centers that appear to have seen any long-term growth of nucleated settlement were the port areas, whose populations appear, in any case, to have continued to fluctuate seasonally. It was precisely those enclaves that precipitated the breakup of the state of Majapahit.

\section{The Economics of Decentralization}

There is a tendency in academic literature for rural communities to be equated with isolation, ignorance, and poverty, and for economic systems not served by an orderly placement of greater and lesser urban centers to be equated with inefficiency and inelasticity. Neither of these truisms seems to be supported by the early Javanese data. States of early Java were demographically dispersed, but by no means inefficient in their handling of flows of goods and information. Java's lucrative trade with the Spice Islands was financed by exports of rice, beans, and other staple crops (Mananjung charter, eleventh century), and, by the twelfth century, Java had become a major producer and exporter of black pepper, feeding the Chinese market. The list of taxable goods traded in Javanese rural markets of the time included tin from Malaya, copper from China and mainland Southeast Asia, iron from sources perhaps as distant as the East African coast, silver perhaps from Burma, and gold from many sources. With these metals came dyestuffs from the forests of Borneo and Sumatra and from the dry islands of the Lesser Sundas, skeins of silk from China and of cotton from Bali and the east Javanese lowlands, salt and salt fish from the coast, and other regional products from Java itself. Local pottery was widely traded and Chinese ceramics 
are so widely dispersed in non-elite sites after the tenth century 32 that they must have circulated through the market system. Chinese reports of the twelfth and thirteenth centuries speak of exports to Java not only of such finished goods as silk cloth, lacquer-ware, ceramics, and cast iron implements, but also of a wide range of industrial chemicals used in dyeing and metal working. ${ }^{33}$ Gold and silver coins were minted in both central and east Java, ${ }^{34}$ and they were used by all strata within the society to pay taxes and debts, and to purchase everything from cloth and buffaloes to land and buildings. At the same time Java imported Chinese copper cash, and the boundless Javanese appetite for copper coinage seriously worried Chinese treasury authorities after the turn of the millennium. So much of this versatile small-denomination coinage appears to have been in circulation in Java by the fourteenth century that it was adopted as the standard currency. By the standards of the time, Java's economy - both domestic and import-export-was efficient and its market sophisticated.

Several factors appear to have contributed to this efficiency in the flow of goods through an obstinately rural landscape. Administrative involvement appears to have been largely passive in nature, even in the import-export trade. In this sector Javanese rulers of successive states seem to have resorted, like their later counterparts, to tax farming as a means of acquiring income without reforming the very decentralized tax-collecting system. ${ }^{35}$ These tax farmers apparently included in their ranks both local and foreign merchants, ${ }^{36}$ and port areas seem to have become the foci of collection of taxes in kind, and of administered sales at fixed prices, largely in connection with rice, black pepper, beans, salt, and wungkudu dye, from the coastal regions in their immediate vicinity, under authorities other than the court and political hierarchy. This development of an alternative administration of major classes of taxation in the vicinity of ports may have been a key factor in the eventual breakdown of the Majapahit state during the trade boom of the fifteenth century. The Javanese court seems not to have been equipped to deal with the increasingly autonomous, powerful, and wealthy enclaves it had inadvertantly created by trying to derive maximum benefit from the export of agricultural produce without reforming its own administrative structure and practices. Since ports appear also to have become centers of industries dependent upon imported raw materials (the main iron-working centers of east Java were, for instance, located in the Surabaya-Sidoarjo coastal region ${ }^{37}$ ), and they harbored large fishing industries, $^{38}$ it is not surprising that these areas began to develop characteristics reminiscent of the Malay states of neighboring islands, whose economic and administrative arrangements were broadly similar. ${ }^{39}$

Port areas aside, the economy of Javanese states remained largely decentralized. Although the ports played an essential role in providing a number of critically important

32 Orsoy de Flines, "Onderzoek" and Wisseman, "Archaeological Research."

${ }^{33}$ F. Hirth and W. W. Rockhill (trans. and ed.), Chau Ju-kua: His Work on the Chinese and Arab Trade in the Twelfth and Thirteenth Centuries, entitled Chu-fan-chi (New York: Paragon Reprints, 1966), p. 78.

${ }^{34}$ R. S. Wicks, "Monetary Developments in Java between the Ninth and Sixteenth Centuries: a Numismatic Perspective," Indonesia 42 (1986): 42-77.

${ }^{35}$ See, for instance, the charters of Watukura (tenth century), Manañjung (eleventh century), and Garamān (eleventh century).

36 Christie, "Patterns," pp. 252-68.

37 See the charters of Sangguran ( 928 C.E.) and Manarijung (eleventh century).

38 See Dhimañāśrama (eleventh century).

${ }^{39}$ Christie, "Patterns," pp. $332 \mathrm{ff}$. 
goods and raw materials for circulation, and in renewing supplies of copper currency and bullion to feed the domestic economy, they appear not to have become central places in the classic sense. Some of the more valuable and prestigious finished goods, such as Indian cottons and swords, Chinese silks and ceramics, and so forth, may have gone to the court in the first instance as payment for tax farms, and from there trickled down to other members of the state. Most of the more mundane items-and many of the more valuable items as well-seem to have entered the interlocking networks of circulating markets of the interior fairly directly, without passing through any identifiable intermediate level of centers of distribution of goods.

Markets and the trade associated with them are mentioned frequently and prominently in the sima charters, particularly of the tenth and eleventh centuries. These markets (pkan) circulated amongst groups of neighboring communities, at the village rather than hamlet level, on a five day schedule (this Javanese five-day week also bearing the name of $p k a n$ ). By the tenth century, if not before, the market held on the day Kliwon in the five-day market week appears to have been the dominant market of the circuit, ${ }^{40}$ feeding goods into those held on other days in the same catchment area. These markets drew varying ranges and volumes of trade, those in the densely populated and apparently well-off Brantas delta region providing a particularly impressive range of goods and services. The professional traders who frequented them were expected to cover large territories in their circuits, as they still are today ${ }^{41}$ No single trader's circuit could, however, have carried goods from the coast to the far interior. Such a distance could only have been covered by overlapping and interlocking circuits in patterns still present in the market systems of central and east Java for some goods. ${ }^{42}$ While metal-workers may have developed their own network based upon port industries and relations to certain exclusive holy places, most of the trade in perishables seems, as early as the tenth century, to have been handled through a system very similar in broad terms to that still present in rural Javanese market networks.

The key to this system is the bakul trader, a market-based trader who buys from farmers and peddlars and sells both locally (on a retail basis) and to carriers moving on to other markets (on a wholesale basis). The modern bakul is, in turn, wholesaler, retailer and provider of credit, bulking goods for more distant markets and breaking down lots that arrive from outside. Without the bakul, modern Java's market system, which can operate in the absence of large urban supply-markets, would collapse. This entrepreneur appears, under the name of adagang bakulan ("bakul trader") or abakul, as early as the beginning of the tenth century, operating in the larger markets of the Brantas delta communities, ${ }^{43}$ though not, apparently, in markets at the ports themselves. They seem to have been then, as now, the essential middlemen who kept trade moving:

... those bakul traders who trade in areca and betel ... sesame and oil ... all the produce of the marshes ... tamarind ... cotton ... may receive goods from other, distant

\footnotetext{
40 See the charter of Waharu (931 C.E.).

41 The most common formula to be found in passages relating to the removal or transfer of state taxes on certain classes of trader is similar to that found in the charter of Patakan (eleventh century), which states that thise traders "are not to be subject to the sang mangilala drawya haji tax collectors, no matter what region they go to..." The Kambang Putih charter (eleventh century) is more explicit, stating that these traders are not to be subject to state tax "should they trade to the limits of the kingdom of His Majesty."

42 See A. Dewey, Peasant Marketing in Java (New York: Free Press, 1962); G. Chandler, Market Trade in Rural Java (Clayton: Monash University Centre of Southeast Asian Studies, Papers on Southeast Asia, No. 11, 1984); J. Alexander, Trade, Traders and Trading in Rural Java (Singapore: Oxford University Press, 1987).

43 Christie, "Patterns," p. 224.
} 
regions and sell them in the neighborhood without being subject to the merchant tax farmers of the five regions.... (Garaman charter, 1053 C.E. $)^{44}$

... those who act as bakul traders, handling all the contents of the dry rice fields, all the contents of the sawah fields, all the contents of the marshes, all the contents of the sea, all the contents of the mountain slopes-two of each only [shall be freed from tax].... (Tuhanaru and Kusambyan charter, 1323C.E.). ${ }^{45}$

The bakul-centered market network sustained flows of goods of at least certain classes through the heartlands of the east Javanese states. Whether they performed the same functions in the earlier markets of central Java is less clear, since passages in sima charters of the ninth century are less specific in relation to trade. The periodic market system does, however, appear to have been a major agency through which horizontal cohesion was maintained at the village level in all of the early states documented by inscriptions. By the ninth century, administrative groupings of villages under watek heads were already too dispersed to perform this function. The fact that the states of early central Java were even less "urbanized" than their east Javanese successors may indicate that a trader similar to the bakul was already beginning to appear in markets of the central Javanese interior.

This bakul system does not seem to have led to the formation of markets above a certain size-nor does it seem to have generated permanent, daily markets specializing in wholesale trade. It may be that this manner of articulating wholesale and retail trade was self-limiting in its scale. If so, then the sima system of state finance for religious foundations, with its commercial tax concessions, must have reinforced this tendency to limitation in scale of operations. The tax provisions of the charters of the ninth century were fairly vague and sweeping. By the tenth century, however, when market trade began to receive greater administrative attention, limits were imposed upon the volume of trade that could be carried on by individual professionals resident in sima villages without being subject to state taxes. Since limitations were also placed upon the number of professionals who could operate free of these taxes within a given community, this may have reduced competition; it certainly ensured dispersal of such professional trading activity. The sima tax concessions must have encouraged the build-up of trade in the affected community until it reached the tax ceiling (assuming, of course, that the religious community to which the tax rights were transferred was not overly greedy in exercising those rights). But the same concessions must have discouraged growth in professional trading activity beyond that ceiling.

New finds of charters continue to be made, and the exact provenance of some of those found in the past is uncertain, but from the record as it now stands, it seems that the pattern of creation of sima territories was correlated more closely with periods and areas of population growth than with those of temple building, particularly in east Java. Thus, the creation of sima trading enclaves must, to some extent, have kept pace with the growth of consumption demand and of the market network as a whole. This may have acted as a brake on the growth of commercial centers in the interior. At least thirty such sima trading enclaves appear to have been established in the Brantas delta and on its fringes between 900 and 1060 C.E., all in areas with the population, wealth, and transport infrastructure to produce commercial towns or even cities but which, in fact, did not.

In sum, then, a number of factors may have contributed to the failure of clearly urban centers to develop in the populous heartlands of the early states of Java. The major ones-

\footnotetext{
44 Transcribed and translated by Drs. M. Boechari, but not yet published.

45 Brandes, Oud-Javaansche, Ixxxiii.
} 
the nature of Javanese communities and their persistent tendency to subdivide into smallish residential clusters within traditional village territories that were large enough to accommodate a good deal of rural sprawl, and the decentralized, periodic, bakul-centered market network that supplied those communities-were reinforced, and even amplified, by certain of the states' administrative procedures and peculiarities. These included the sima taxtransfer system and tax-farming arrangements that obviated the need for administrative centralization of state finances, as well as the relative mobility of the political center. Political ties and tax rights in Java tended, over time, to devolve into somewhat unstable and territorially unfocused chains of patron-client ties, as tax-collecting authority, like everything else, tended to subdivide rather than accumulate.

Urbanization is not a process which can be automatically coupled with that of state-formation and development: in central and east Java, population growth and the increase of wealth and trade appear to have encouraged growth of communities of the interior only until they reached a threshold beyond which fission began to occur. Those coastal enclaves which managed to pass that threshold eventually detached themselves from the main body of the state, becoming the foci of smaller states of a somewhat different nature. 